\title{
INFLUENCE OF ALLOYING ELEMENTS ON THE MECHANICAL PROPERTIES OF A COBALT-BASED ALLOY PRODUCED WITH POWDER METALLURGY
}

\author{
VPLIV LEGIRNIH ELEMENTOV NA MEHANSKE LASTNOSTI \\ OSNOVNE KOBALTOVE ZLITINE, PRIDOBLJENE \\ Z METALURGIJO PRAHOV
}

\author{
Kateřina Nová, Pavel Novák, Drahomír Dvorský \\ University of Chemistry and Technology, Department of Metals and Corrosion Engineering, Technická 5, 16628 Prague 6, Czech Republic \\ novakx@vscht.cz \\ Prejem rokopisa - received: 2016-03-31; sprejem za objavo - accepted for publication: 2016-07-28
}

doi:10.17222/mit.2016.054

\begin{abstract}
This work was focused on studying the effect of alloying elements on the mechanical and tribological properties of cobalt alloys. The Co-Cr-Mo alloy has been successfully used for the production of orthopaedic implants thanks to a better wear resistance than that of titanium implants. However, with the development of scientific and technological processes, there is still an ongoing effort to further improve the wear resistance and other properties of cobalt-based alloys. The aim of this research was to find a suitable alloying element, which would increase the wear resistance, while the other characteristics remain unimpaired. When choosing such an element, we have to keep in mind that it has to be non-toxic for the human body. The standard Co-Cr-Mo alloy and Co-Cr-Mo alloy with various alloying elements, specifically $\mathrm{Nb}, \mathrm{Si}$, Ti in an amount of $5 \%$ mass fraction, were prepared using mechanical alloying followed by the compacting method called spark-plasma sintering. The influences of the alloying elements on the microstructure as well as mechanical and tribological properties were observed. Based on the obtained results, the Co-Cr-Mo-Nb alloy seems to be most suitable because the addition of niobium greatly improved the wear resistance. However, it is necessary to perform many other tests, especially the tests of corrosion resistance and biocompatibility.
\end{abstract}

Keywords: cobalt alloy, biomaterial, mechanical properties, wear resistance

Delo je bilo osredotočeno na preučevanje vpliva legirnih elementov na mehanske in tribološke lastnosti kobaltnih zlitin. Co-Cr-Mo zlitina je bila uspešno uporabljena za izdelavo ortopedskih implantantov, zahvaljujoč boljši odpornosti proti obrabi, kot jo nudijo vsadki iz titana. Vendar z razvojem znanstvenih in tehnoloških procesov še vedno potekajo prizadevanja za izboljšanje odpornosti proti obrabi in izboljšanje drugih lastnosti zlitin na osnovi kobalta. Cilj raziskave je bil najti primerno primešani element, ki bi povečal odpornost proti obrabi, medtem ko druge lastnosti ostajajo nedotaknjene. Pri izbiri takega elementa, moramo imeti v mislih, da mora biti nestrupen za človeško telo. Standardna Co-Cr-Mo zlitina in tudi Co-Cr-Mo zlitina z različnimi legirnimi elementi, zlasti $\mathrm{Nb}, \mathrm{Si}, \mathrm{Ti}$, v $5 \%$ masnem deležu, sta bili pripravljeni s sintranjem. Opažen je bil vpliv legirnih elementov na mikrostrukturo, kot tudi mehanskih in triboloških lastnosti. Na osnovi dobljenih rezultatov se zdi, da je Co-Cr-Mo-Nb zlitina najbolj primerna, saj je dodatek niobija zelo izboljšal odpornost proti obrabi. Vendar pa je potrebno izvesti še številne druge teste, zlasti preizkuse odpornosti proti koroziji in biokompatibilnost.

Ključne besede: kobaltna zlitina, biološki material, mehanske lastnosti, odpornost proti obrabi

\section{INTRODUCTION}

Metallic materials are very promising for biomedical use and the attention devoted to them is growing. The metallic materials for biomedical application may be biodegradable and non-degradable materials. The most attractive candidates from the second group include titanium and its alloys, cobalt-based alloys as well as stainless steel. Co-based alloys, particularly Co-Cr-Mo and $\mathrm{Co}-\mathrm{Cr}-\mathrm{W}$, are known under the commercial name of Stellites. ${ }^{1}$ Thanks to their excellent resistance to degradation in the oral cavity, they were originally used in medicine for casting dental implants. Over time, cobalt alloys began use as surgical implants. Nowadays, due to a better wear resistance than that of the titanium alloy, they are widely used for the orthopaedic prostheses for the knee, shoulder and hip, and for fracture fixation. These are typical long-term implants. Cobalt endo- prostheses are non-magnetic, have suitable mechanical properties, corrosion resistance to the body fluids and also a good biocompatibility with the body's environment. $^{2-4}$

The mechanical properties of cobalt-based alloys, and of the other metallic materials, are primarily dependent on the chemical composition, microstructure and their manufacturing processes. ${ }^{5}$ Pure cobalt exists in two allotropic modifications. While at temperatures below $417{ }^{\circ} \mathrm{C}$, cobalt exhibits a hexagonal close-packed structure, above this temperature, a face-centred cubic one is stable. ${ }^{5,6}$ Many properties of the Co-Cr-Mo alloy originate from the crystallographic structure of cobalt. The alloying elements - $\mathrm{Cr}$ and $\mathrm{Mo}$ - have a solid-solution-strengthening effect. Besides $\mathrm{Cr}$ and $\mathrm{Mo}$, the alloy always contains a small amount of carbon, which forms extremely hard carbides in the structure. The size and 
distribution of the carbides in the alloy have a significant effect on the mechanical properties and wear resistance. ${ }^{2,7}$ Chromium has the highest affinity to carbon, so initially chromium carbide was formed $-\mathrm{Cr}_{23} \mathrm{C}_{6}$. The formation of these carbides decreases the content of the unbound chromium applicable to the formation of the passive layer that protects the material against corrosion. ${ }^{6}$ Cobalt-based alloys have excellent corrosion resistance mainly due to this thin layer of chromiumbased oxide. ${ }^{8}$ In literature, there are numerous studies associated with testing the corrosion resistance and biocompatibility of the Co-Cr-Mo alloy for medical applications and even variants with additions of $\mathrm{Zr}, \mathrm{Cu}$ and N. ${ }^{9-11}$ Nitrogen was tested mainly to improve the ductility of the alloy by stabilizing the fcc structure. ${ }^{11}$ However, there is a lack of the studies dealing with the improvement of the wear resistance to limit the amount of wear debris in big joints during the lifetime of an implant.

The cobalt alloy - Co-Cr-Mo - for orthopaedic applications is processed mainly by casting, but may also be wrought. The casting method is preferred for complex shaped products. Because the cooling rate is different in each part of the casting, the resulting structure may be coarse and non-homogeneous. Wrought material has better mechanical properties as it has a finer and homogeneous structure without pores. ${ }^{3}$ In recent years, powder metallurgy has been commonly used for preparing materials with high purity, exact chemical compositions, desirable structures and porosity. In a material prepared with the powder-metallurgy method, there is always a certain proportion of pores. ${ }^{12}$

Based on the described theory, the following alloying elements were selected: $\mathrm{Ti}, \mathrm{Si}$ and $\mathrm{Nb}$. It was assumed that they would form carbides $(\mathrm{Ti}, \mathrm{Nb})$ or silicides $(\mathrm{Si})$ in the alloy, which would improve the wear resistance as well as the mechanical properties. In this paper, the Co-Cr-Mo alloys with the additions of the above-mentioned alloying elements were prepared with the powder metallurgy using novel two-stage mechanical alloying ${ }^{13}$ and spark-plasma sintering. The aim of the work was to develop ultrafine-grained cobalt alloy with improved wear resistance.

\section{MATERIALS AND METHODS}

The standard Co-Cr-Mo alloy and also the Co-Cr-Mo alloy with various alloying elements, specifically $\mathrm{Nb}, \mathrm{Si}$, Ti in an amount of $5 \%$ mass fraction (Table 1) were prepared from elemental powders with mechanical alloying under a protective argon atmosphere followed by a spark-plasma-sintering (SPS) compaction. The mechanical alloying, wherein the carbon was added as graphite, was completed in a Retsch PM 100 CM planetary ball mill as a two-stage process, patented by the authors. ${ }^{13}$ The first stage, used for the homogenization of the powder mixture, was carried out for $30 \mathrm{~min}$ with a rotation speed of $200 \mathrm{~min}^{-}$. In the second stage, devoted to mechanical alloying, the milling time increased to $60 \mathrm{~min}$ and the rotational speed to $500 \mathrm{~min}^{-1}$. The method of spark-plasma sintering (SPS) was carried out under the following conditions: $1100{ }^{\circ} \mathrm{C}$, $5 \mathrm{~min}, 50 \mathrm{MPa}$.

Table 1: Chemical composition of standard Co-Cr-Mo alloy Tabela 1: Kemijska sestava standardne Co-Cr-Mo zlitine

\begin{tabular}{|c|c|c|c|c|}
\hline & $\mathrm{Co}(w / \%)$ & $\mathrm{Cr}(w / \%)$ & $\mathrm{Mo}(w / \%)$ & $\mathrm{C}(w / \%)$ \\
\hline Sample & 65.75 & 28.0 & 6.0 & 0.25 \\
\hline
\end{tabular}

The phase composition was examined with an X-ray diffraction analysis using a PANalyticalX'Pert Pro diffractometer with a Co anode. The microstructures of the samples were observed after etching with modified Kroll's reagent $\left(5 \mathrm{~mL} \mathrm{HNO}_{3}+10 \mathrm{~mL} \mathrm{HF}+85 \mathrm{~mL} \mathrm{H}_{2} \mathrm{O}\right)$ on a metallographic microscope Olympus PME3 and a TESCAN VEGA 3 LMU scanning electron microscope equipped with an Oxford Instruments X-max $20 \mathrm{~mm}^{2}$ EDS detector with the Aztec software package. The hardness was measured with the Vickers method on the standard hardness tester with a load of $30 \mathrm{~kg}$ (HV30). Each measurement was repeated ten times. The abrasion wear behaviour was evaluated using the pin-on-disk method, where the pin was the tested material and the disk was the P1200 grinding paper. The abrasive distance was $2.5 \mathrm{~km}$ and the applied load was $5.8 \mathrm{~N}$. Each sample was weighed before and after the test. The wear rate was calculated from the measured weight loss using Equation (1), where is $w$ - the wear rate $\left(\mathrm{mm}^{3} \mathrm{~m}^{-1}\right), \Delta \mathrm{m}-$ the weight loss $(\mathrm{g}), \rho$ - the density $\left(\mathrm{g} \mathrm{cm}^{-1}\right), l-$ the abrasive distance $(\mathrm{m})$ :

$$
W=\frac{\Delta m \cdot 1000}{\rho l}
$$

\section{RESULTS AND DISCUSSION}

The phase composition of an individual alloy was determined with X-ray diffraction. Each alloy type is composed of cobalt with a hexagonal and cubic structure. An increase in the amount of the hop phase is observable in titanium- and niobium-alloyed materials. On the other hand, silicon lowers the content of hexagonal cobalt (Table 2). In addition to cobalt-based solid solutions, the Co-Cr-Mo alloy also contained $\mathrm{Cr}_{23} \mathrm{C}_{6}$ carbide and traces of the $\mathrm{Co}_{2} \mathrm{C}$ phase. In niobium- and silicon-alloyed materials, $\mathrm{NbC}$ carbide and $\mathrm{Cr}_{3} \mathrm{Si}$ phase were determined, respectively. When titanium was added, no titanium-based phase appeared, leading to the same phase composition as in the case of the standard Co-Cr-Mo alloy. It implies that titanium was completely dissolved in the Co-based solid solution, or that the amount of the Ti-containing phase was below the detection limit of XRD. The phase composition is shown in Figure 1. 
Table 2: Weight percentage of individual phases in Co-Cr-Mo-X alloys (determined with XRD)

Tabela 2: Masni delež posameznih faz v Co-Cr-Mr-X zlitinah (določen z XRD-analizo)

\begin{tabular}{|c|c|c|c|c|}
\hline Phase & Co-Cr-Mo & $\begin{array}{c}\text { Co-Cr-Mo- } \\
\text { Nb }\end{array}$ & $\begin{array}{c}\text { Co-Cr-Mo- } \\
\mathrm{Si}\end{array}$ & $\begin{array}{c}\text { Co-Cr-Mo- } \\
\text { Ti }\end{array}$ \\
\hline Co (fcc) & 68 & 59 & 75 & 62 \\
\hline $\mathrm{Co}(\mathrm{hcp})$ & 28 & 39 & 18 & 35 \\
\hline $\mathrm{Cr}_{23} \mathrm{C}_{6}$ & 4 & - & - & 3 \\
\hline $\mathrm{NbC}_{\mathrm{Cr}}$ & - & 2 & - & - \\
\hline $\mathrm{Cr}_{3} \mathrm{Si}$ & - & - & 7 & - \\
\hline
\end{tabular}

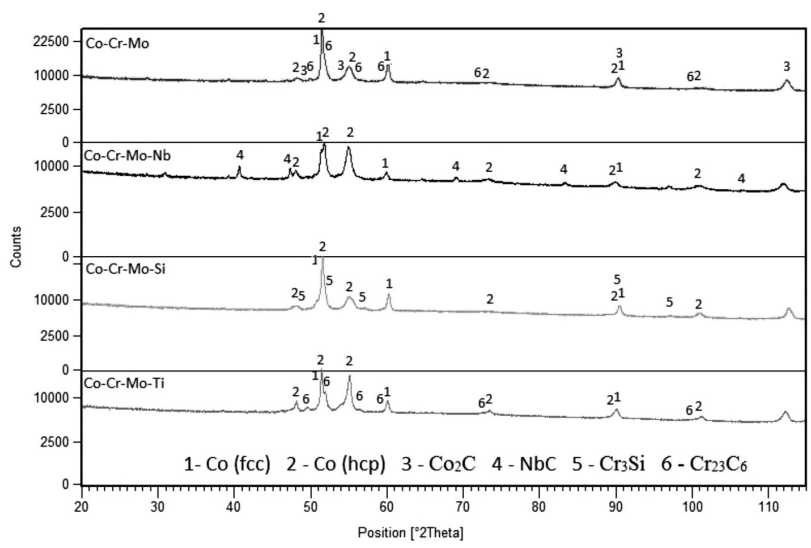

Figure 1: Phase composition

Slika 1: Sestava faze
The differences in the ratio between the hexagonal and cubic cobalt-based solid solutions can be explained with the following theory: niobium forms carbides instead of chromium due to a higher affinity to carbon. Therefore, there is more chromium dissolved in the cobalt-based matrix. According to the Co-Cr binary phase diagram, chromium stabilizes the hcp cobalt. ${ }^{14}$ In the case of titanium, the stabilization of the hcp structure is probably due to the similarity of the crystal structure of $\alpha$-Ti (hcp) and the hexagonal cobalt. The opposite effect of silicon probably occurs due to the formation of chromium silicide $\left(\mathrm{Cr}_{3} \mathrm{Si}\right)$ instead of the chromium carbide. Therefore, there is more carbon in the matrix. According to the Co-C equilibrium phase diagram ${ }^{14}$, carbon is more soluble in the high-temperature cubic modification of cobalt and, therefore, it is able to stabilize it.

Figure 2 shows the microstructures of the samples acquired with an optical microscope. All the alloys are slightly porous (up to 6 area $\%$ by image analysis), which is due to the poor compressibility and sinterability of cobalt alloys. All the alloys are composed of a fcc cobalt-based solid solution (darker grey), hcp cobalt (light grey to white) and intermediary phases (carbides or silicide depending on the alloy composition) - dark grey to black. This confirms the results of XRD. It is evident that the microstructure of $\mathrm{Co}-\mathrm{Cr}-\mathrm{Mo}$ is very
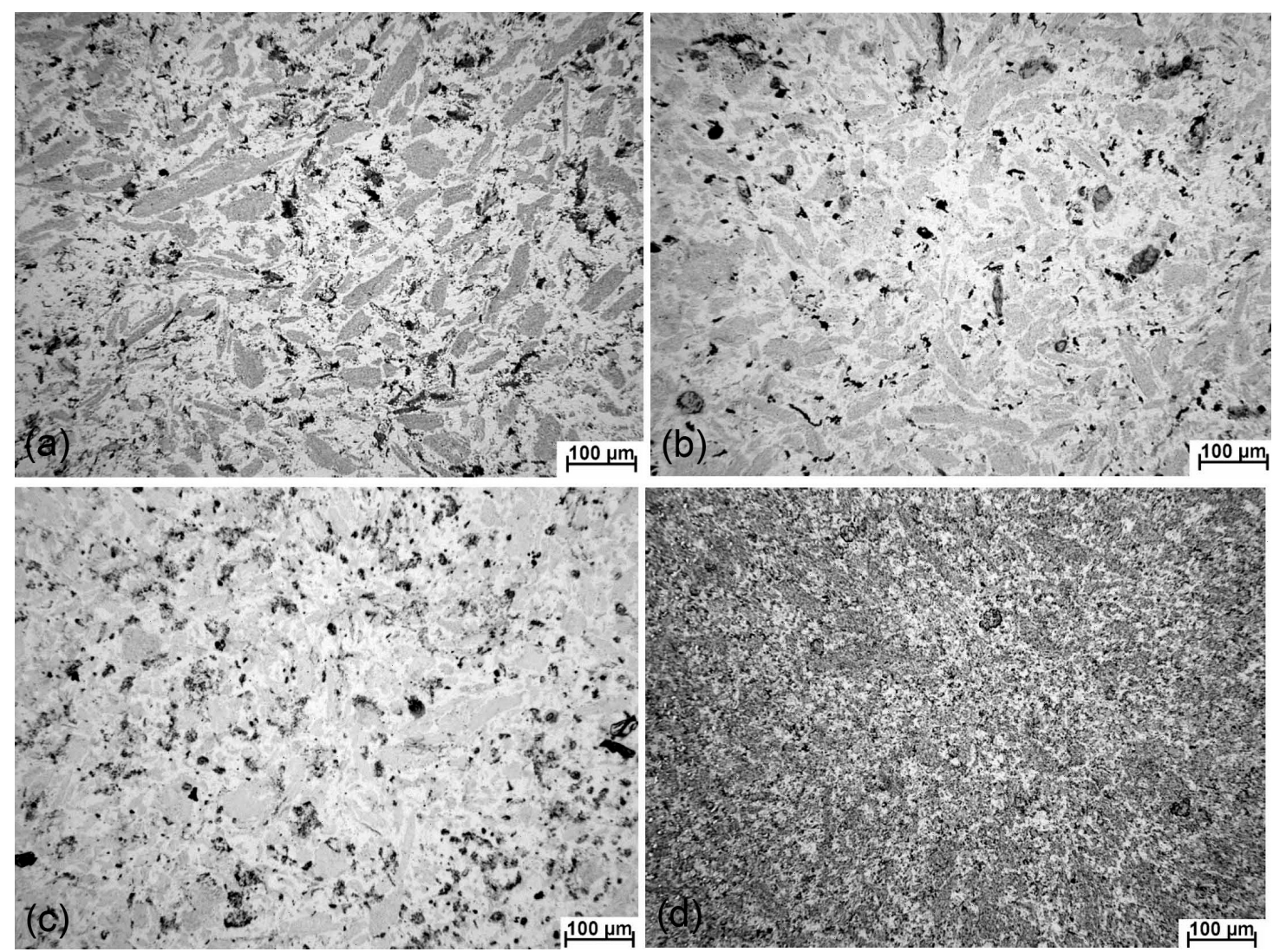

Figure 2: Microstructures of: a) Co-Cr-Mo, b) Co-Cr-Mo-Nb, c) Co-Cr-Mo-Ti and d) Co-Cr-Mo-Si

Slika 2: Mikrostrukture: a) Co-Cr-Mo, b) Co-Cr-Mo-Nb, c) Co-Cr-Mo-Ti in d) Co-Cr-Mo-Si 
K. NOVÁ et al.: INFLUENCE OF ALLOYING ELEMENTS ON THE MECHANICAL PROPERTIES ...

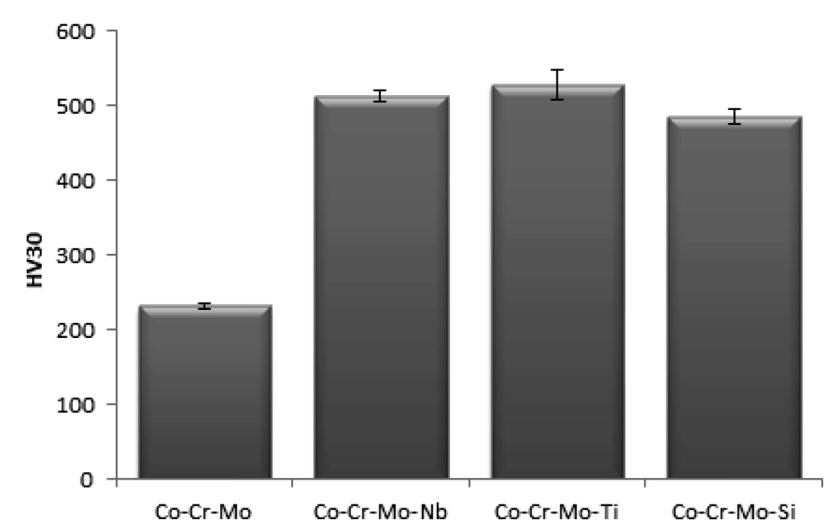

Figure 3: Hardness versus alloy composition

Slika 3: Trdnost v primerjavi s sestavo zlitine

similar to the samples alloyed with titanium and niobium, differing only in the fcc : hcp cobalt ratio. For Co-Cr-Mo-Si, we see a more visible difference in the microstructure, i.e., a significant grain refinement.

The hardness significantly increases with the addition of any alloying element (Figure 3). The reason is probably the solid-solution strengthening of the titaniumand silicon-alloyed material, as well as the formation of a dispersed hard phase in the niobium-containing alloy. This was confirmed with the EDS analysis, showing the average content of niobium in the matrix of only $1.6 \%$ mass fraction, while in the titanium- and silicon-alloyed materials, the amounts of titanium and silicon reach 4.9 $\%$ mass fraction and $3.9 \%$ mass fraction, respectively (Table 3).

Table 3: Average chemical composition of the matrix (in mass fraction $(w / \%)$, determined with EDS)

Tabela 3: Povprečna kemijska sestava matrice (v masnih deležih $(w / \%)$, določena z EDS-analizo)

\begin{tabular}{|c|c|c|c|c|c|c|}
\hline Alloy & $\mathrm{Co}$ & $\mathrm{Cr}$ & $\mathrm{Mo}$ & $\mathrm{Ti}$ & $\mathrm{Si}$ & $\mathrm{Nb}$ \\
\hline Co-Cr-Mo & 65.9 & 28.0 & 6.1 & - & - & - \\
\hline Co-Cr-Mo-Nb & 64.0 & 29.3 & 5.1 & - & - & 1.6 \\
\hline Co-Cr-Mo-Si & 63.1 & 27.4 & 5.6 & - & 3.9 & - \\
\hline Co-Cr-Mo-Ti & 62.4 & 27.3 & 5.4 & 4.9 & - & - \\
\hline
\end{tabular}

The results of the test of the wear resistance are presented in Figure 4. It is evident that titanium only slightly improved the wear resistance, but the alloying with niobium has a more significant influence. This result corresponded with the previous finding obtained with an XRD analysis, which revealed the presence of dispersed hard niobium carbide in the $\mathrm{Nb}$-alloyed material. It is known that the presence of hard particles improves the wear resistance more than the solid-solution-strengthening effects even though the hardness is comparable. In the case of the Co-Cr-Mo-Si alloy, the wear resistance is much poorer in comparison with the standard Co-Cr-Mo alloy. This can be caused by two possible phenomena - the presence of brittle chromium silicide and the stabilization of the fcc cobalt structure by

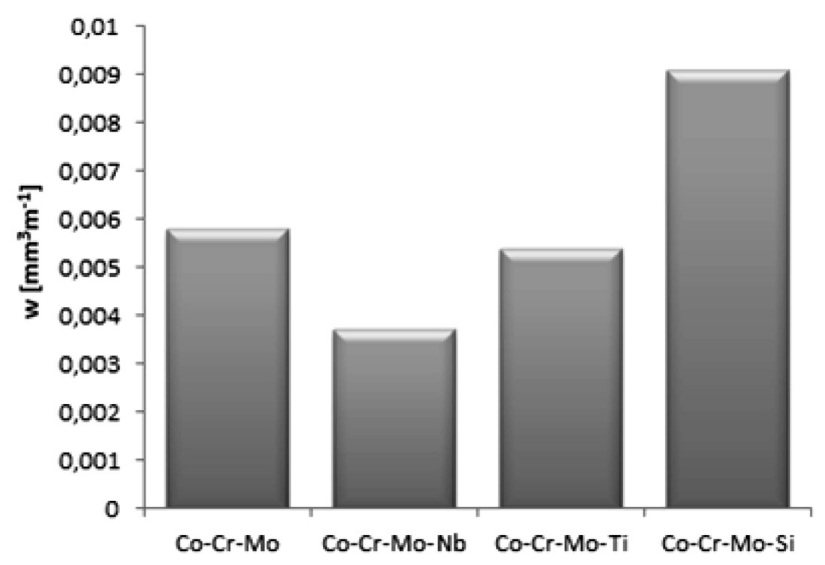

Figure 4: Abrasive-wear rate versus alloy composition Slika 4: Abrazijska stopnja obrabe v primerjavi s sestavo zlitine

silicon. The fcc structure exhibits a higher plasticity and, therefore, the material removal is easier.

\section{CONCLUSION}

The presented results indicate that after the additions of alloying elements $-\mathrm{Nb}, \mathrm{Si}, \mathrm{Ti}-$ in all the cases, the hardness increases. This correlates well with the changes in the phase composition, producing hard phases (NbC) or reinforcing the material mainly with the solid-solution-strengthening effect ( $\mathrm{Ti}, \mathrm{Si}$ ). On the other hand, only some of the elements simultaneously improve the abrasive-wear resistance. The measurement of the abrasion resistance was crucial for us because the aim was to specifically improve this property. From this point of view, the alloying with silicon is absolutely unsatisfactory. The best wear resistance was achieved for the $\mathrm{Co}-\mathrm{Cr}-\mathrm{Mo}-\mathrm{Nb}$ alloy, wherein the addition of niobium significantly reduced the wear rate. $\mathrm{Co}-\mathrm{Cr}-\mathrm{Mo}-\mathrm{Nb}$ thus appears to be the best solution, but it is necessary to perform many more tests, especially the tests of corrosion resistance and biocompatibility.

\section{Acknowledgement}

This research was financially supported by the Czech Science Foundation, project No. P108/12/G043.

\section{REFERENCES}

${ }^{1}$ H. Ö. Gülsoy, Ö. Özgün, S. Bilketay, Powder injection molding of Stellite 6 powder: Sintering, microstructural and mechanical properties, Materials Science and Engineering A, 651 (2016), 914-924, doi:10.1016/j.msea.2015.11.058

${ }^{2}$ A. Marti, Cobalt-base alloys used in bone surgery, Injury, 31 (2000) 4, D18-D21, doi:10.1016/S0020-1383(00)80018-2

${ }^{3}$ J. Cawley et al., A tribological study of cobalt chromium molybdenum alloys used in metal-on-metal resurfacing hip arthroplasty, Wear, 255 (2003) 7-12, 999-1006, doi:10.1016/S0043-1648(03) 00046-2

${ }^{4}$ C. Sawangrat et al., Application of Harmonic Struture Design to Biomedical Co-Cr-Mo alloy for Improved Mechanical Properties, Materials Transaction, 55 (2014) 1, 99-105, doi:10.2320/matertrans. MA201303 


\section{MATERIALI IN TEHNOLOGIJE/MATERIALS AND TECHNOLOGY (1967-2017) - 50 LET/50 YEARS}

\section{K. NOVÁ et al.: INFLUENCE OF ALLOYING ELEMENTS ON THE MECHANICAL PROPERTIES ..}

${ }^{5}$ J.-C. Shin et al., Effect of molybdenum on the microstructure and wear resistance of cobalt-base Stellite hardfacting alloys, Surface and Coatings Technology, 166 (2003) 2-3, 117-126, doi:10.1016/ S0257-8972(02)00853-8

${ }^{6} \mathrm{G}$. Bellefontaine, The corrosion of CoCrMo alloys for biomedical applications, Doctoral dissertation, University of Birmingham, 2010

${ }^{7}$ T. Matković, P. Matković, J. Malina, Effects of Ni and Mo on the microstructure and some other properties of $\mathrm{Co}-\mathrm{Cr}$ dental alloys, Journal of alloys and compounds, 366 (2004) 1-2, 293-297, doi:10.1016/j.jallcom.2003.07.004

${ }^{8}$ R. Zupančič, A. Legat, N. Funduk, Electrochemical and mechanical properties of cobalt-chromium dental alloy joints, Materials and technology, 41 (2007) 6, 295-300

${ }^{9}$ P. Stenlund, S. Kurosu, Y. Koizumi, F. Suska, H. Matsumoto, A. Chiba, A. Palmquist, Osseointegration Enhancement by Zr doping of Co-Cr-Mo Implants Fabricated by Electron Beam Melting, Additive Manufacturing, 6 (2015), 6-15, doi:10.1016/j.addma.2015.02.002
${ }^{10}$ E. Zhang, C. Liu, A new antibacterial Co-Cr-Mo-Cu alloy: Preparation, biocorrosion, mechanical and antibacterial property, Materials Science and Engineering C, 69 (2016), 134-143, doi:10.1016/ j.msec.2016.05.028

${ }^{11}$ K. Yamanaka, M. Mori, A. Chiba, Nanoarchitectured Co-Cr-Mo orthopedic implant alloys: Nitrogen-enhanced nanostructural evolution and its effect on phase stability, Acta Biomaterialia, 9 (2013), 6259-6267, doi:10.1016/j.actbio.2012.12.013

${ }^{12}$ R. W. Cahn, P. Haasen, E. J. Cramer, Processing of metals and alloys, Materials Science and Technology, 15 (1991) 193, doi:10.1002/cite. 330640225

${ }^{13}$ P. Novák, CZ Patent 305703, 2014

${ }^{14}$ T. B. Massalski, Binary Alloy Phase Diagrams, ASM, Materials Park, 1990 